\title{
Visualization of power supply network interference in telemedicine systems of mobile electrocardiography
}

\author{
Y.G. Gorshkov ${ }^{1}$ \\ Bauman Moscow State Technical University, Russian Federation \\ ${ }^{1}$ ORCID: 0000-0003-0483-4603, y.gorshkov@npo-echelon.ru
}

\begin{abstract}
The article presents the continuation of the author's research in the field of visualization of biomedical signals in the development and operation of mobile cardiodiagnostic systems. Some of the latest guidelines for developers of electrocardiographic equipment and recommendations for the frequency range of the ECG signal for standard clinical use are considered. The negative impact of industrial frequency interference (power supply network interference) on the analyzed signal is emphasized. The hardware and software solutions of means of removal and registration of interference of the power supply network are offered, including a laryngophone headset with a small-sized condenser digital USB microphone and a sound editor. During the period 2010-2020, 1092 phonograms of acoustic biomedical heart signals, network interference and electromagnetic interference in various rooms were recorded. To solve the problems of visualization of power supply network interference, the capabilities of the common audio editor Audacity were evaluated. The necessary timefrequency resolution was not achieved using the examples of the obtained spectral sections of the signal sections with interference. The developed software tools WaveView and WaveViewMWA are presented, which provide high frequency-time resolution and visual visualization of small-level interference due to multi-level wavelet analysis of non-stationary signals.

Experimental testing of the proposed visualization technology has confirmed its high efficiency. For the first time, a set of typical power supply network interference signals was obtained when registering biomedical cardiodiagnostic signals under real operating conditions of mobile systems. An example of noise visualization using the portal is given acustocard.ru in on-line mode.
\end{abstract}

Keywords: telemedicine systems, power supply network interference, mobile electrocardiography, multi-level wavelet analysis.

\section{Introduction}

Cardiovascular diseases (CVD) are one of the leading causes of all deaths in the world. According to the World Health Organization (WHO), about 17 million people die from CVD every year. Cardiovascular diseases include strokes, heart attacks, and coronary heart disease. About 1.3 million people die from diseases of the cardiovascular system every year in Russia, which is about $55 \%$ of the total number of deaths $[1,2]$. Among the non-invasive methods of studying the cardiovascular system (CCC), electrocardiography (ECG) retains a priority. ECG is the most affordable, relatively cheap, and least time-consuming method of examination. Daily outpatient ECG monitoring using the Holter method has become widespread. Resting ECG and daily monitoring are currently the main research methods at all stages of the management of cardiac patients. Recent studies have shown that increasing reliability and effectiveness of cardiodiagnostics is possible through the creation of intelligent ECG monitoring systems using technologies such as deep learning, artificial intelligence, big data, and the Internet of Things [3, 4]. 
The entry into force of the law on telemedicine in our country from January 1, 2018 allowed us to start solving the problems of introducing telemedicine complexes for remote electrocardiographic studies into medical practice [5]. The direction of mobile electrocardiography (MECG) has been developed [6-8]. At the same time, when it is possible to use small-sized ECG devices in almost any conditions, the real electromagnetic environment is not always taken into account, the type and level of electrical interference of the $50 / 60 \mathrm{~Hz}$ industrial frequency power supply signals is determined, which can ultimately lead to measurement errors and unreliability of diagnostic data.

In recent years, in our country, the developers of equipment for recording and processing ECG signals of telemedicine systems have taken into account the influence of only interference of the industrial frequency of $50 \mathrm{~Hz}$ [9-13]. The effect of harmonics of $100 \mathrm{~Hz}$ and $150 \mathrm{~Hz}$ on the cardiac signal is usually not taken into account. Foreign experts in this field offer solutions to eliminate 50-6o Hz interference signals [14-23]. In one of the latest publications [24], the authors, in addition to the interference of the fundamental frequency of $60 \mathrm{~Hz}$, consider the effect on the ECG signal of the second and third harmonics $(120 \mathrm{~Hz}$ and $180 \mathrm{~Hz}$ ). Thus, the solution of the problem of high-precision isolation and visualization of the entire set of interference, including harmonics of frequencies of 5o/60 $\mathrm{Hz}$, located in the frequency band of the electrocardiographic signal and leading to errors in the diagnosis of diseases of the cardiovascular system, should be considered relevant.

\section{ECG signal recording and processing}

A considerable amount of work has been devoted to the study of methods for recording ECG signals and development of devices for recording heart biopotentials on the surface of the human body. Currently, the contact method of ECG registration is most widely used in medical practice. The China Applications Support Team of Analog Devices has developed "Guidelines for the development of the hardware part of the module for ECG registration" [25], which fully contains the information necessary for developers of electrocardiographic equipment.

Fig. 1 shows a generalized form of the ECG signal indicating the characteristic values of the measured parameters [25].

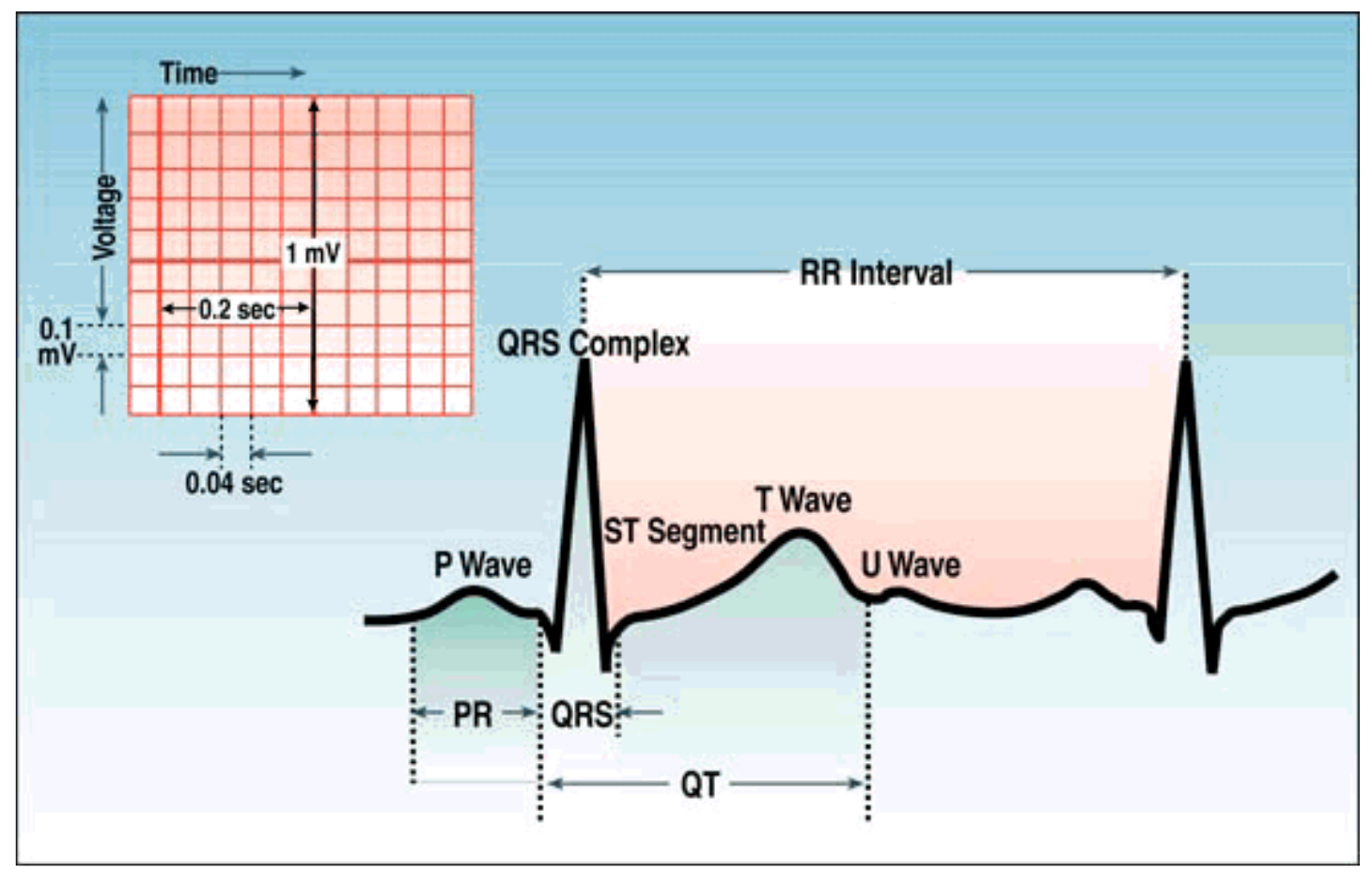

Fig. 1. ECG signal shape and characteristic values of its parameters 
Based on the information presented in Figure 1, it follows that when analyzing the ECG parameters, we have to deal with signals of several millivolts. The frequency range of the ECG signal is limited to several hundred Hertz, while for standard clinical use, you can limit the band from $0.05 \mathrm{~Hz}$ to $100 \mathrm{~Hz}$. The signal in this frequency band will experience the negative impact of interference frequency $50 / 60 \mathrm{~Hz}$ (noise interference of the power supply).

Also in [25], attention is drawn to other types of interference affecting the ECG signal: electromagnetic interference from various electronic devices; - noise resulting from changes in the conditions of contact of the electrode with the skin; - distortion of the signal when the patient moves, associated with a change in the impedance of the electrode-skin contact; - human muscle activity.

Fig. 2 shows the appearance of the "home cardioanalyzer" (LLC "ITM-Myocard", NIMP ESN and Laboratory of Artificial Intelligence, Russia) and an example of ECG signal visualization [26].
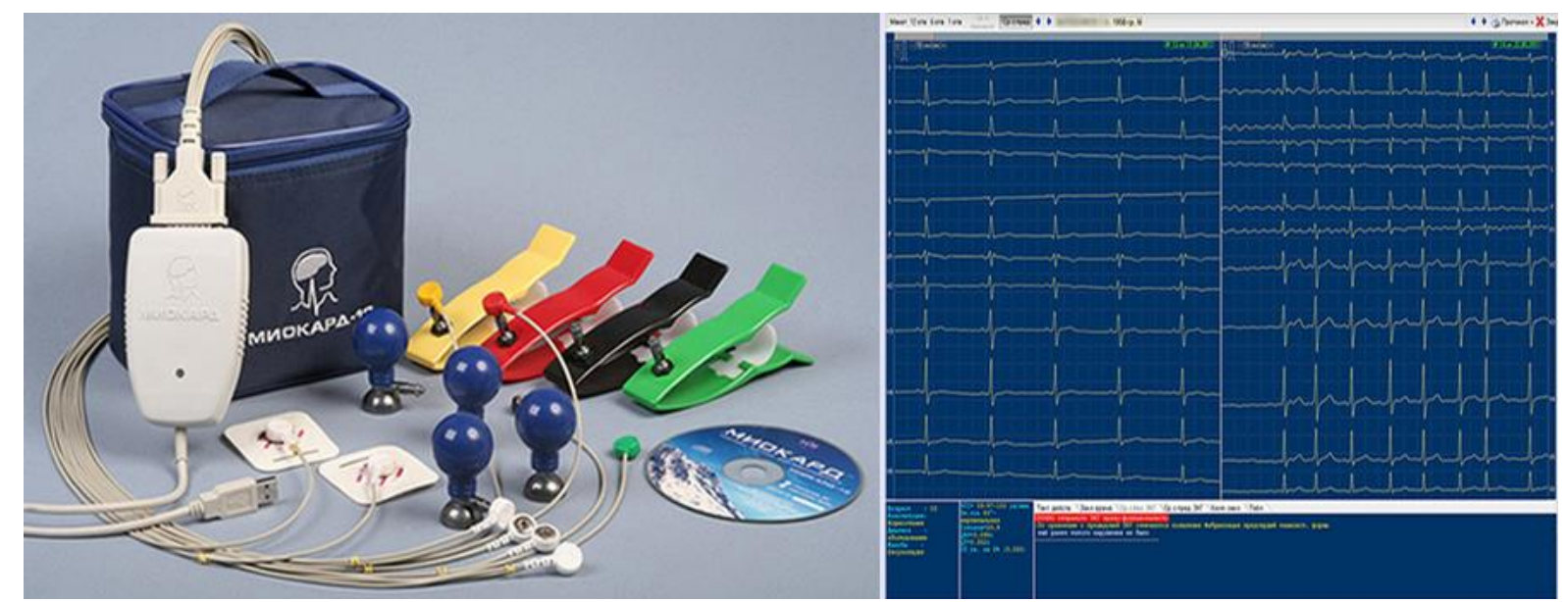

Fig. 2. The appearance of the "home cardioanalyzer" and an example of ECG signal visualization

A significant increase in the reliability of diagnosing patients is achieved by engineering and methodological support for metrological assessment of the state of the used tools. For the effective use of ECG devices in telemedicine systems, automated systems of metrological verification and certification tests "on the ground" are being developed [27]. The active development of cardiac monitoring systems based on the analysis of the variability of heart rate parameters necessitates the accurate detection of QRS complexes of the ECG signal to minimize errors in measuring the duration of R-R intervals of the ECG signal (Fig. 1) under the influence of the above interference [28, 29].

\section{Means of removing and processing power supply network interference}

\subsection{Hardware and software tools for recording power supply interference signals (PSP)}

As a device for removing power supply interference signals, a laryngophone headset with a small-sized digital USB condenser microphone is used. The headset is fixed in the neck area, it provides the recording of heart sounds, interference, as well as analog-to-digital signal conversion. The recording path includes a Logitech PC Headset 960 USB ("Logitech", USA), a frequency range of 20-20000 Hz (Fig. 3), and an AD Sound Recorder ("Adrosoft") [30]. WAV recording format, mono mode, sampling rate $11025 \mathrm{~Hz}$, bit depth 16 bits. 


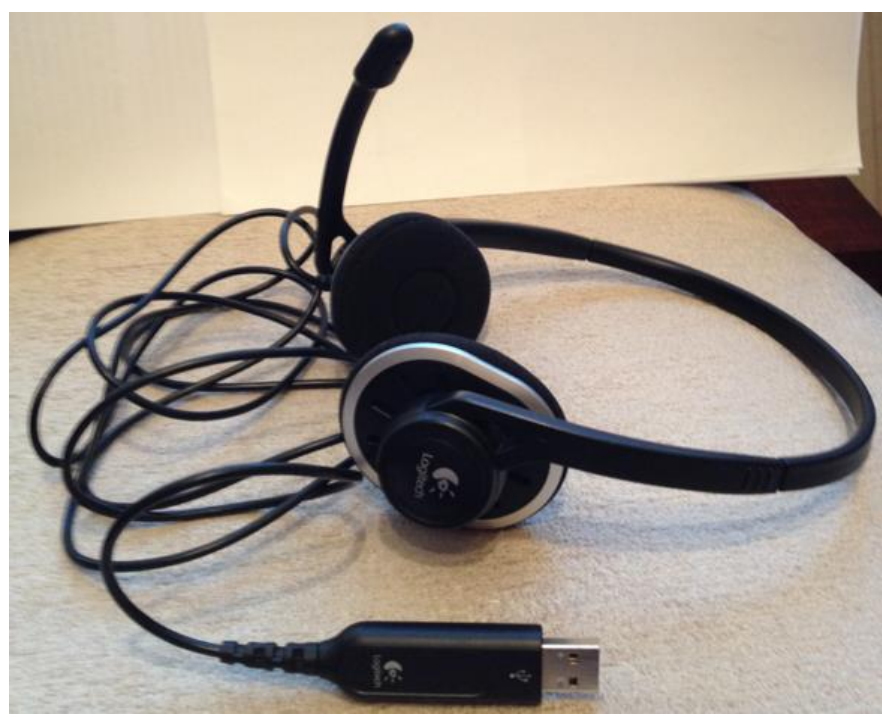

Fig. 3. Appearance of the Logitech PC Headset 960 USB

\subsection{Software tools for visualization of PSP signals using the Fourier transform}

Consider the possibilities of one of the most common audio editor Audacity processing audio recordings in the time-frequency visualization of heart sounds with power supply interference. The Audacity editor provides the following functions: spectral analysis using the Fourier transform with different window shapes; noise removal from the sample [31]. Fig. 4 shows the waveform of the recorded signal with interference.

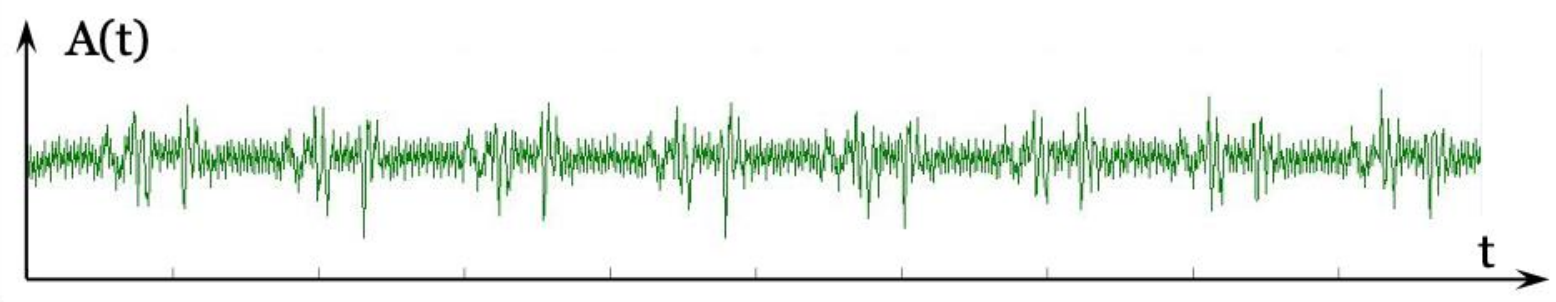

Fig. 4. Waveform of the registered signal with interference

Fig. 5 shows the spectral cross-section of the signal section with interference of $50 \mathrm{~Hz}$ and $150 \mathrm{~Hz}$, obtained by the Audacity editor. The interference level with a frequency of $5 \mathrm{O} \mathrm{Hz}$ is $-20 \mathrm{~dB}$, with a frequency of $150 \mathrm{~Hz}-52 \mathrm{~dB}$.

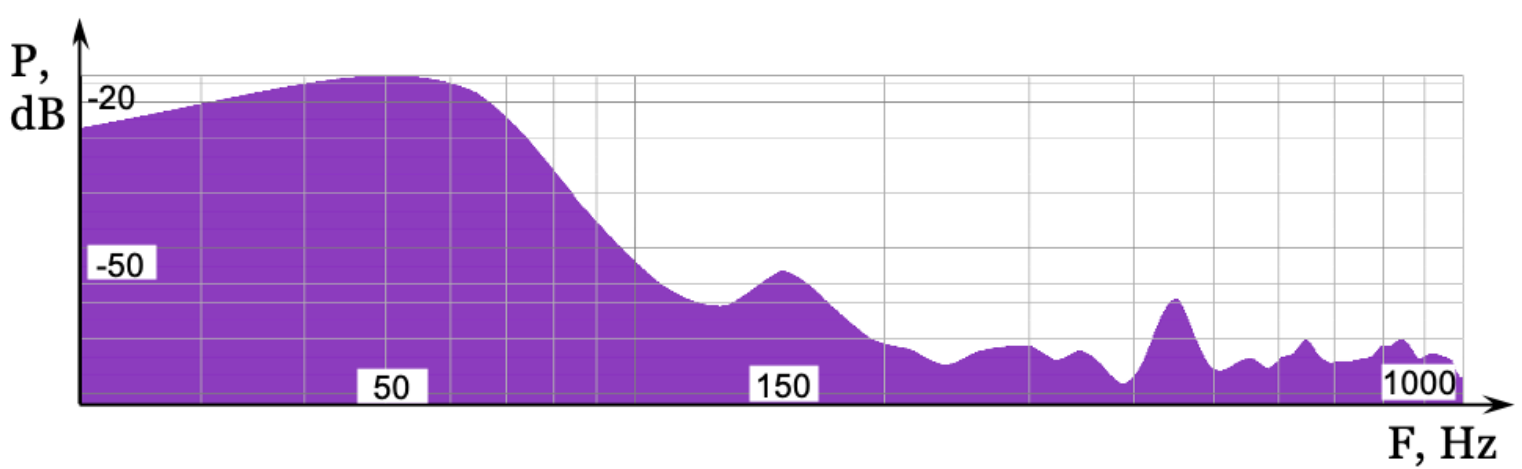

Fig. 5. Spectral cross-section of the signal section with interference 
The analysis of the data in Fig. 5 shows that the use of the Fourier transform in the analysis of interference signals does not provide the necessary accuracy and visual visualization of the frequency components.

\subsection{Software tools for visualization of PSP signals using multi- level wavelet analysis (MWA)}

Research aimed at creating software tools for high-precision processing and visualization of non-stationary signals led to the creation of WaveView and WaveView-MWA programs [32]. WaveView features: analysis of the signal section with the ability to select the frequency band and time-frequency resolution; display of the analysis results in the form of a wavelet sonogram ("visible sound" images), using the mother Morle wavelet; obtaining the frequency section at a given time; support for a large number of audio file formats. The WaveView-MWA software is the latest version of the wavelet analysis software. When constructing acoustic phonograms, the mother wavelets are used: Morle, Haara,"Mexican hat". Testing on WaveView-MWA showed the ability to isolate and visualize non-stationary signals of a small level up to $-60 \mathrm{db}$. The use of WaveView-MWA in solving problems of determining the authenticity of phonograms [33], acoustic research of heart and lung sounds [34-36], visualization of biomedical signals in telemedicine systems [37, 38], provides accuracy that is not available for digital processing based on the Fourier transform.

\section{Examples of wavelet sonograms of PSP signals}

In the course of studies conducted at the Bauman Moscow State Technical University for the period 2009-2019, using hardware and software tools for taking and processing acoustic biomedical heart signals, as well as the impact of network interference and electromagnetic interference on acoustocardiography (ACG) signals, an analysis of 1092 records recorded in various rooms was performed. Consider examples of wavelet sonograms obtained using WaveView-MWA.

Fig. 6 shows the wavelet sonograms of typical power supply interference signals (A, B, C, D) recorded in different rooms.

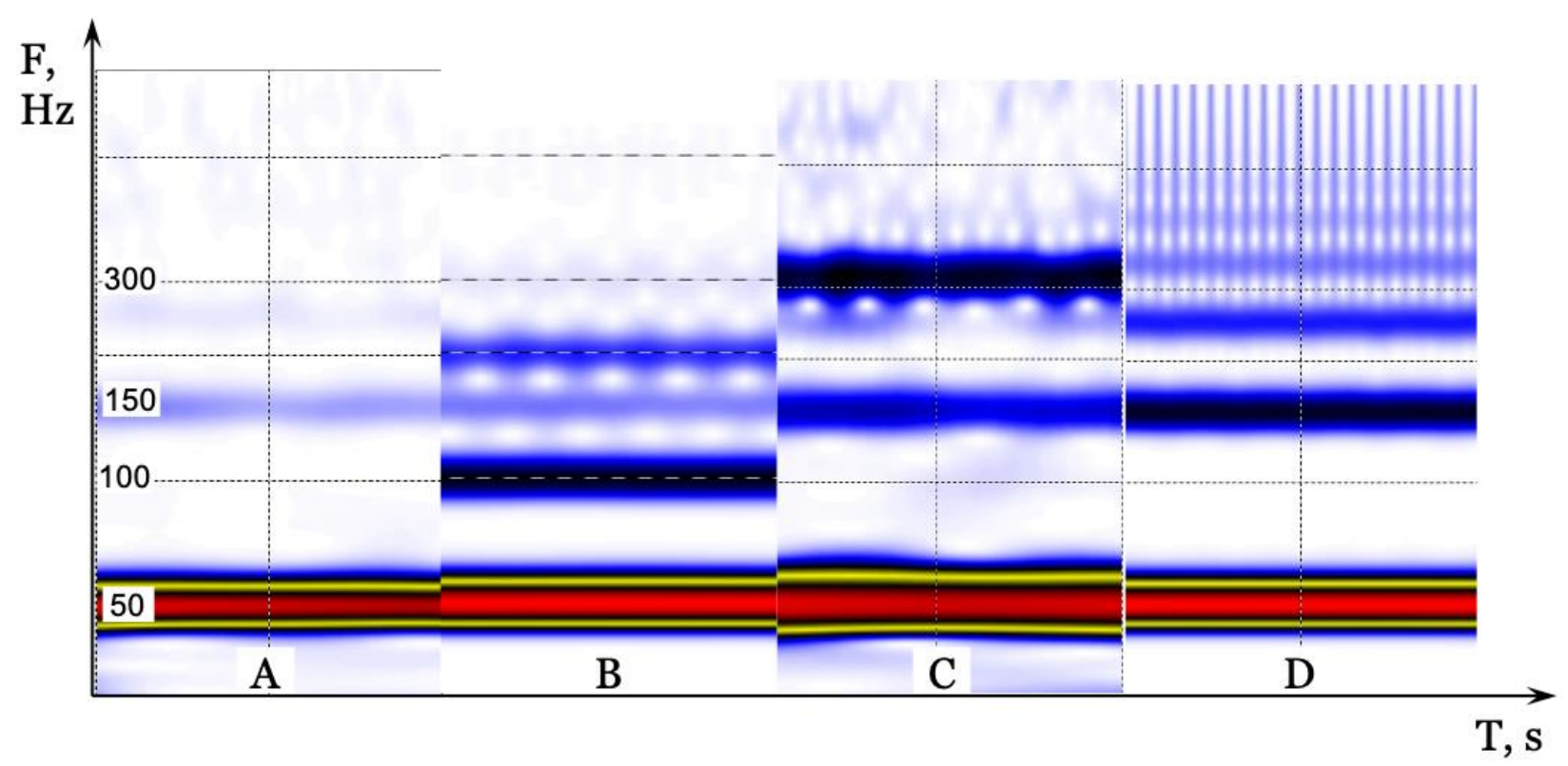

Fig. 6. Wavelet sonograms of typical power supply interference signals 
Where A: frequency components of interference of $50,150 \mathrm{~Hz}$ (the waveform of the signal is shown in Fig. 4. Fourier spectrogram - Fig. 5); B: 50, 100, 150, 200 Hz; C: 50, 150, 300 $\mathrm{Hz}$; D: 50, 150, 250, 350, $450 \mathrm{~Hz}$.

In addition to the typical interference of the power supply network with a frequency of 50 $\mathrm{Hz}$, there are interference in the form of harmonics, for example, 150, $300 \mathrm{~Hz}$ (Fig. 7).

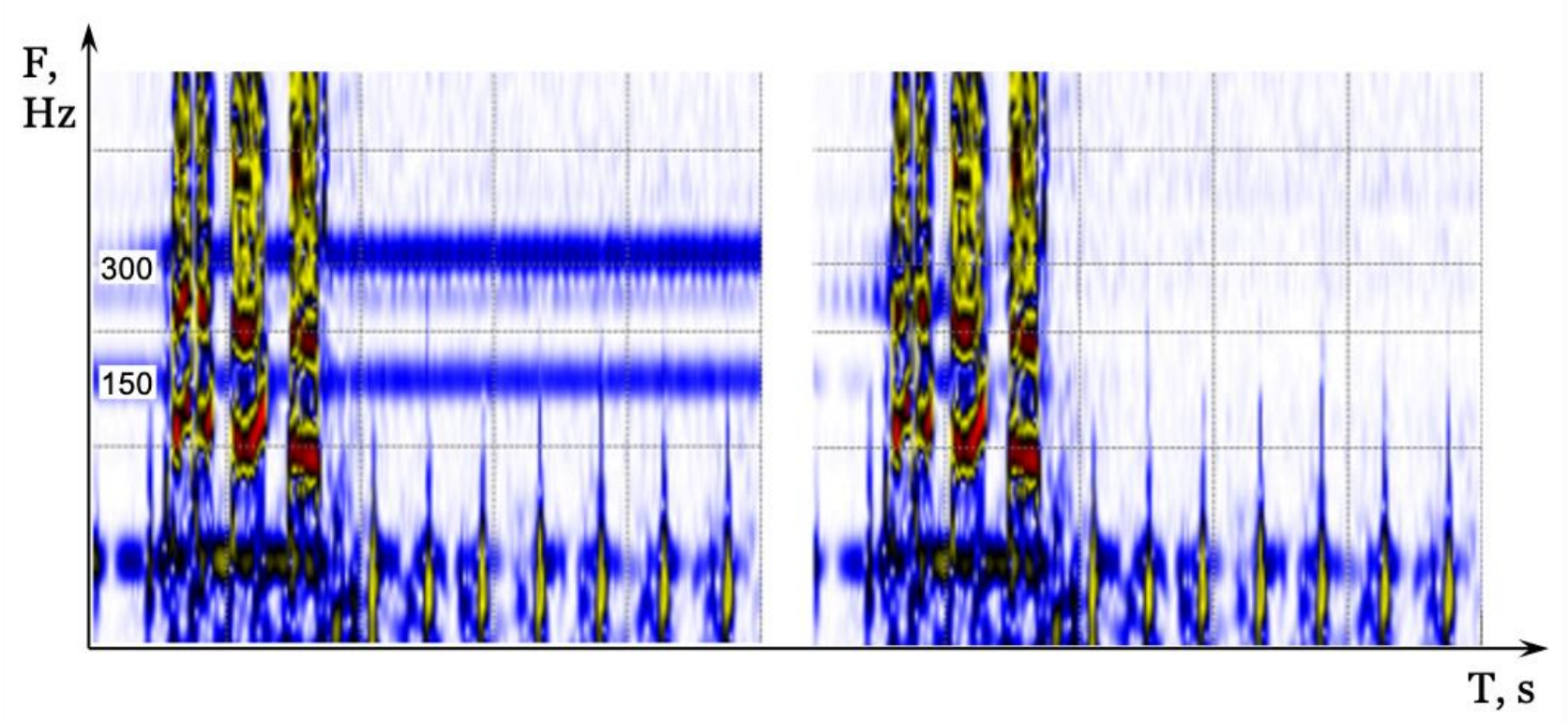

Fig. 7. Wavelet sonograms of acoustic biomedical speech signals and heart tones with interference of $150,300 \mathrm{~Hz}$ (left) and after noise cleaning (right)

Noise cleaning of signals from interference after the visualization stage and determination of frequency characteristics is also provided by WaveView-MWA using Daubechies, Coifman, and Shannon filters.

One example of the effect of power supply interference on ACG signals is shown in Fig. 8. The wavelet sonogram of the signal with $50 \mathrm{~Hz}$ interference was obtained using the portal acustocard.ru in on-line mode.

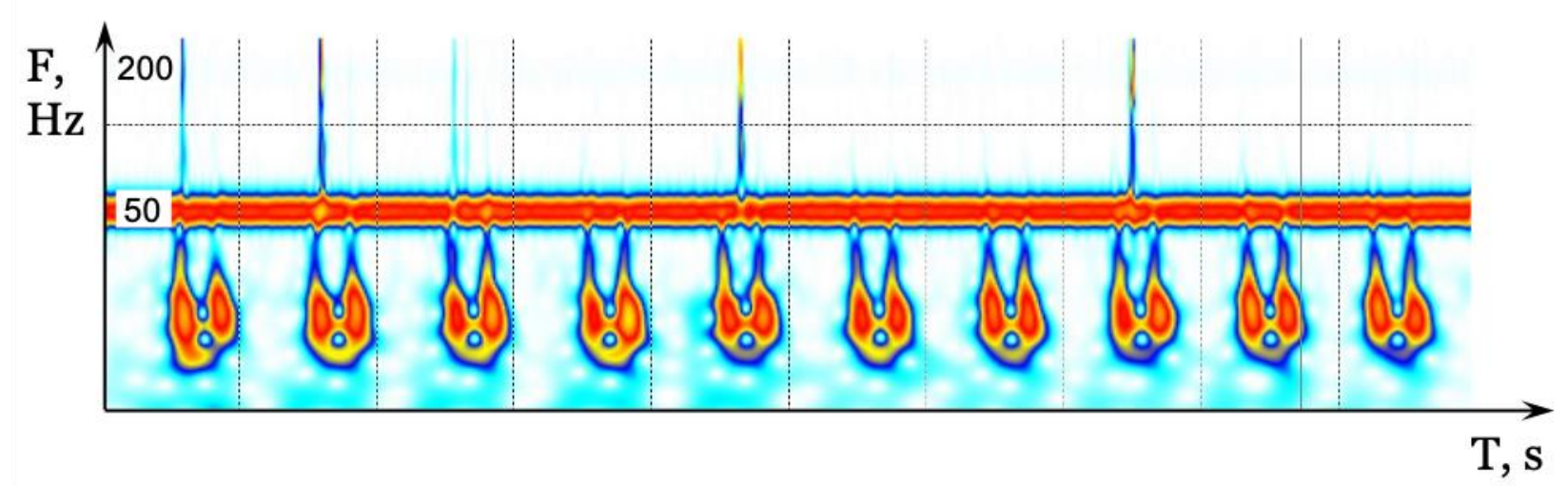

Fig. 8. Wavelet sonogram of heart tones with interference of $50 \mathrm{~Hz}$, the band of analyzed frequencies of $10-200 \mathrm{~Hz}$

Fig. 9 shows the acoustic signal after removing the $50 \mathrm{~Hz}$ interference. 


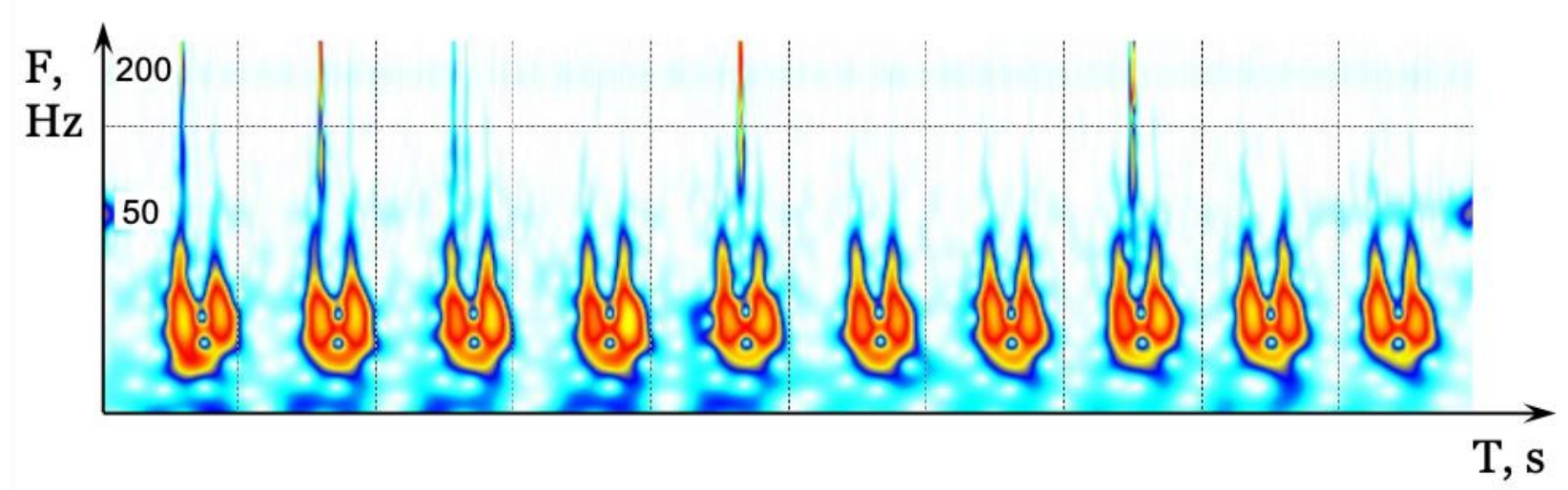

Fig. 9. Wavelet sonogram of heart tones without interference

Analysis of the interference images presented in Fig. 6-9 shows that the wavelet sonograms are much more informative than the usual Fourier spectrograms and, unlike the latter, allow you to easily identify the finest local features of both acoustic signals and electromagnetic signals of power supply interference.

\section{Conclusion}

With the introduction of telemedicine systems of mobile electrocardiography into medical practice, which provide registration and processing of signals in various electromagnetic environments, current issues include the identification and visualization of electromagnetic interference that negatively affects the ECG signal.

Hardware and software tools for taking, recording and high-precision visualization of power supply network interference and electromagnetic interference are proposed. A set of typical signals of power supply network interference during the registration of biomedical cardiodiagnostic signals in real operating conditions of mobile systems has been identified. The possibility of visualization of interference in the on-line mode is shown.

Obtaining accurate interference parameters and taking them into account in the analysis of ECG signals will increase the reliability of the information obtained and avoid errors in the diagnosis of cardiac diseases.

\section{References}

1. Statistika smertnosti ot serdechno-sosudistykh zabolevaniy v Rossii i v mire / Vsemirnaya organizatsiya zdravookhraneniya. https://www.who.int/ru/newsroom/factsheets/detail/cardiovascular-diseases-(cvds) (Access date: 03.02.2020). [in Russian].

2. Serdtse bez sboyev: kak predotvratit' serdechno-sosudistyye zabolevaniya? Federal'nyy fond obyazatel'nogo meditsinskogo strakhovaniya. http://www.ffoms.ru/(Access date: 03.02.2020). [in Russian].

3. Serhani, M.A.; T. El Kassabi, H.; Ismail, H.; Nujum Navaz, A. ECG Monitoring Systems: Review, Architecture, Processes, and Key Challenges. Sensors 2020, 20, 1796. (https://doi.org/10.3390/s20061796)

4. Porumb M., Stranges S., Pescapè A., Pecchia L. Precision Medicine and Artificial Intelligence: A Pilot Study on Deep Learning for Hypoglycemic Events Detection based on ECG. Scientific Reports, 2020; 10(1). (DOI: 10.1038/s41598-019-56927-5)

5. Prikaz Minzdrava RF ot 30 noyabrya 2017 № $965 \mathrm{n}$ «Ob utverzhdenii poryadka organizatsii i okazaniya meditsinskoy pomoshchi s primeneniyem telemeditsinskikh tekhnologiy». [in Russian].

6. Kozlovskaya I.L., Lopukhova V.V., Bulkina O.S., Karpov YU.A. Telemeditsinskie tekhnologii v kardiologii. Chast' 1 . Personal'nyy telemonitoring ehlektrokardiogrammy 
v ambulatornoy praktike: vybor optimal'nogo podkhoda. Doktor.Ru, 2020, 19(5), pp. 35-41. (DOI: 10.31550/1727-2378-2020-19-5-35-41). [in Russian].

7. I.A. Lezhnina, A.A. Uvarov, K.V. Overchuk, A.A. Boyakhchyan, S.N. Torgayev, G.S. Yevtushenko. Portativnyy besprovodnoy kardioanalizator individual'nogo primeneniya. Meditsinskaya tekhnika, 2019, №6(318), pp. 14-17. [in Russian].

8. TELEEHKG - mobil'naya telemeditsinskaya set'dlya EHKG issledovaniy IBP RAN. https://www.ibp-ran.ru/ (Access date: 03.02.2020). [in Russian].

9. D.N. Katasonov. O sisteme mobil'nogo monitoringa serdechnoy deyatel'nosti cheloveka: poluchenie i fil'tratsiya signalov EHKG. Sbornik nauchnykh trudov NGTU, 2012, No 4(70), pp. 119-130. [in Russian].

10. A.A. Gontarenko, V.P. Kornev. Adaptivnaya fil'tratsiya setevoy pomekhi 50 Gts v sistemakh registratsii ehlektrokardiogramm. Biomeditsinskie pribory i sistemy, 2013, № 4, pp. 45-52. [in Russian].

11. L.YU.Krivonogov, A.E. Klebneva. Sistema testirovaniya algoritmov podavleniya pomekh v ehlektrokardiosignalakh. Izmerenie. Monitoring. Upravlenie. Kontrol', 2013, № 2(4), pp. 51-57. [in Russian].

12. I.A. Lezhnina, A.A. Uvarov, K.V. Overchuk, A.A. Boyakhchyan, S.N. Torgaev, G.S. Evtushenko. Portativnyy besprovodnoy kardioanalizator individual'nogo primeneniya. Meditsinskaya tekhnika, 2019, № 6, pp. 14-17. [in Russian].

13. E.A. Altay, A.S. Kremlev. Formirovanie kompleksnogo podkhoda dlya analiza obrabotki izmeritel'noy ehlektrokardiograficheskoy informatsii. Sbornik tezisov XIV Mezhdunarodnogo Kongressa «KARDIOSTIM». Sankt-Peterburg, 27-29 fevralya 2020, p. 155. [in Russian].

14. R. Huamani R., J.R. Talavera, E.A.S. Mendoza, N.M. Dávila, E. Supo. Implementation of a real-time $60 \mathrm{~Hz}$ interference cancellation algorithm for ECG signals based on ARM cortex M4 and ADS1298. 2017 IEEE XXIV International Conference on Electronics, Electrical Engineering and Computing (INTERCON), Cusco, 2017, pp. 1-4. (DOI: 10.1109/INTERCON.2017.8079725)

15. B. Singh, P. Singh, S. Budhiraja. Various approaches to minimise noises in ECG signal: A survey, in Proc. 5th Int. Conf. Adv. Comput. Commun. Technol., Feb. 2015, pp. 131137.

16. Mallaparapu K., Krishna B.A., Masthan S. et al.: Analysis of denoising on different signals using new thresholding function. IEEE Conf. Signal Processing Communication Engineering Systems (SPACES 2018), Vijaywada, 2018, pp. 154-162.

17. Liu S., Hsieh C.H., Chen W., Tan T.H. ECG Noise Cancellation Based on Grey Spectral Noise Estimation. Sensors (Basel). 2019 Feb 15, 19(4):798. (DOI: 10.3390/s19040798)

18. Mourad N. ECG denoising algorithm based on group sparsity and singular spectrum analysis, Biomed. Signal Process. Control, 2019, 50, pp. 62-71.

19. Devi R., Tyagi H.K., Kumar D. Performance comparison and applications of sparsity based techniques for denoising of ECG signal. 2019 6th Int. Conf. on Signal Processing and Integrated Networks, SPIN 2019, Noida, India, 2019, pp. 346-351.

20. S. Nurmaini, A. Darmawahyuni, A.N. Sakti Mukti, M.N. Rachmatullah, F. Firdaus, B. Tutuko. Deep learning-based stacked denoising and autoencoder for ECG heartbeat classification, Electronics, vol. 9, № 1, p. 135, Jan. 2020.

21. Vargas R.N., Veiga A.C.P. Electrocardiogram signal denoising by a new noise variation estimate. Res. Biomed. Eng. 36, 13-20 (2020). (https://doi.org/10.1007/s42600-019ooo33-y)

22. Singh P., Pradhan G. A new ECG denoising framework using generative adversarial network, IEEE/ACM Trans. Comput. Biol. Bioinf., 2020. (DOI: 10.1109/TCBB.2020.2976981)

23. M. Wasimuddin, K. Elleithy, A.-S. Abuzneid, M. Faezipour, O. Abuzaghleh. StagesBased ECG Signal Analysis From Traditional Signal Processing to Machine Learning 
Approaches: A Survey, in IEEE Access, vol. 8, pp. 177782-177803, 2020. (DOI: 10.1109/ACCESS.2020.3026968)

24. Lizhe Tan, Jean Jiang. Digital Signal Processing (Third Edition). Fundamentals and Applications. Chapter 8 - Infinite Impulse Response Filter Design. 2019, 903 p.

25. Fountain M., Wenshuai L. Hardware Design Specifications. Project: ECG Monitoring Module. Analog Devices, China Applications Support Team, 2007, 23 p.

26. http://myocard.ru/(Access date: 03.02.2020).

27. Briko A.N., Davydov D.V., Yegorov A.I., Filimonov P.V. Ustroystvo imitatsii biosignalov cheloveka dlya ispytaniy elektrokardiografov. Patent RU 184385 U1. 04.06.2018. [in Russian].

28. A.A. Fedotov. Robastnaya metodika obnaruzheniya QRS-kompleksov EKG-signala. Meditsinskaya tekhnika, 2016, №1(295), pp. 28-31. [in Russian].

29. Ye.A. Altay, A.S. Kremlev, K.A. Zimenko, A.A. Margun. Vliyaniye parametrov fil'tra na tochnost' izmereniya elektrokardiograficheskogo signala. Meditsinskaya tekhnika, 2019, №3(315), pp. 19-22. [in Russian].

30. http://www.adrosoft.com/(Access date: 03.02.2020).

31. https://audacity.ru.uptodown.com/windows (Access date: 03.02.2020).

32. Gorshkov Y.G. Processing of Speech and Acoustic Biomedical Signals Based on Wavelets. Radiotekhnika, Moscow, 2017, 240 p. [in Russian].

33. Gorshkov Y.G. Visualization of multi level wavelet analysis of phonograms // Scientific visualization, 2015, vol. 7, № 2, pp. 96-111.

34. Gorshkov Y.G. Razrabotka kompleksa apparatno-programmnykh sredstv dlya ranney diagnostiki zabolevaniy serdtsa «Akustokardiograf» / Materialy, predstavlennyye na konkurs «Purpurnoye serdtse». Yezhegodnaya natsional'naya premiya v oblasti kardiologii, nominatsiya «Nauchnyy proyekt goda». Moskva, 2009, 10 p. [in Russian].

35. Gorshkov Y.G. Akustograficheskoye issledovaniye zvukov serdtsa i legkikh // Biomeditsinskaya radioelektronika, 2016, № 2, pp. 16-21. [in Russian].

36. Gorshkov Y.G. Visualization of the heart sounds // Scientific visualization, 2017, vol. 9, № 1, pp. 97-111.

37. Gorshkov Y.G. New solutions for visualization of biomedical signals in telemedicine systems // Scientific visualization, 2019, vol. 11, № 2, pp. 56-72. (DOI: 10.26583/sv.11.2.05)

38. Gorshkov Y.G., Volkov A.K., Voinova N.A. et al. Acoustocardiography with Assessment of Emotional Tension from the Voice. Biomed Eng 53, 383-387 (2020). (https://doi.org/10.1007/s10527-020-09948-8) 